\title{
COMMUNITY STUDY OF URINARY pH AND OSMOLALITY
}

\author{
BY \\ W. E. WATERS, M. SUSSMAN, AND A. W. ASSCHER \\ M.R.C. Epidemiological Research Unit (South Wales), and the Departments of Bacteriology and Medicine, \\ Welsh National School of Medicine, Cardiff
}

In a previous communication (Asscher, Sussman, Waters, Davis, and Chick, 1966), it was shown that urine obtained from females supports the growth of $E$. coli, the commonest urinary pathogen, better than that from males. This difference was dependent on a sex difference in urinary $\mathrm{pH}$ and osmolality, the urines of females being significantly more often at suitable $\mathrm{pH}$ and osmolality for the growth of $E$. coli than those of males. This paper describes the detailed results of the community study which led us to conclude that a sex difference in urinary $\mathrm{pH}$ and osmolality exists.

\section{Methods}

Three communities in South Wales were studied. The areas chosen were a small mining town in the Rhondda Fach, a rural village in the Vale of Glamorgan, and a suburban area of Cardiff. These regions were considered to be representative of many such areas in South Wales. In each locality, sixty consecutive occupied houses were selected and a census of the occupants was taken. All persons between the ages of 15 and 65 years were asked to pass a specimen of urine on first rising in the morning. Sterile, $100 \mathrm{ml}$. wide-mouthed jars which contained a $\frac{1}{2}$ " layer of paraffin were provided. The diet of the subjects was not altered in any way. The specimens were picked up as soon as possible after voiding; usually within 90 minutes. They were then transported to the laboratory in refrigerated bags where they were first cultured and then stored at $-10^{\circ} \mathrm{C}$. The $\mathrm{pH}$ and osmolality of the specimens were estimated within a few days of collection by a technician who was not aware of the sex of the urine donors. pH measurements were performed to the nearest 0.05 of a unit using a glass electrode $\mathrm{pH}$ meter (Associated Electrical Industries). Osmolality was determined using a Fiske osmometer (Advanced Instruments Inc.); the mean of three observations was employed as the final value for urine osmolality.

\section{RESULTS}

The census in the three areas gave a total sample of 208 males and 186 females between the ages of 15 and 65 years. Urines were obtained from 200 of the males $(96 \cdot 2$ per cent.) and 178 of the females (95. 7 per cent.). The size of the three populations, response rates, and means of urinary $\mathrm{pH}$ and osmolality are shown in Table $I$.

TABLE I

MEAN pH AND OSMOLALITY OF EARLY MORNING URINE SPECIMENS 200 Males and 178 Females, aged 15 to 65 years, living in three areas in South Wales

\begin{tabular}{|c|c|c|c|c|c|c|c|c|c|c|c|}
\hline \multirow{2}{*}{$\frac{\text { Sex }}{\text { Area }}$} & \multirow{2}{*}{$\cdots$} & \multirow{2}{*}{$\cdots$} & \multirow{2}{*}{$\cdots$} & \multirow{2}{*}{$\cdots$} & \multirow{2}{*}{$\cdots$} & \multicolumn{3}{|c|}{ Male } & \multicolumn{3}{|c|}{ Female } \\
\hline & & & & & & $\underset{\text { Valley }}{\text { Mining }}$ & $\begin{array}{l}\text { Rural } \\
\text { Village }\end{array}$ & Suburban & $\underset{\text { Valley }}{\text { Mining }}$ & $\begin{array}{l}\text { Rural } \\
\text { Village }\end{array}$ & Suburban \\
\hline \multicolumn{4}{|c|}{$\begin{array}{l}\text { Number in Sample } \\
\text { Number of Specimens } \\
\text { Response Rate (per cent.) }\end{array}$} & $\begin{array}{l}\cdots \\
\cdots\end{array}$ & $\begin{array}{l}\cdots \\
\cdots \\
\cdots\end{array}$ & $\begin{array}{l}67 \\
64 \\
95 \cdot 5\end{array}$ & $\begin{array}{l}67 \\
65 \\
97 \cdot 0\end{array}$ & $\begin{array}{l}74 \\
71 \\
95 \cdot 9\end{array}$ & $\begin{array}{l}64 \\
62 \\
96 \cdot 9\end{array}$ & $\begin{array}{l}58 \\
55 \\
94 \cdot 8\end{array}$ & $\begin{array}{l}64 \\
61 \\
95 \cdot 3\end{array}$ \\
\hline $\begin{array}{l}\text { Mean pH } \\
\text { S.D. }\end{array}$ & $\begin{array}{l}\cdots \\
\cdots\end{array}$ & $\begin{array}{l}\cdots \\
\cdots\end{array}$ & $\begin{array}{l}\cdots \\
\cdots\end{array}$ & $\ddot{\cdots}$ & $\cdots$ & $\begin{array}{r}5 \cdot 62 \\
\cdot 49\end{array}$ & $\begin{array}{r}5 \cdot 58 \\
\cdot 44\end{array}$ & $\begin{array}{r}5 \cdot 57 \\
\cdot 44\end{array}$ & $\begin{array}{r}5 \cdot 79 \\
\cdot 52 \\
\end{array}$ & $\begin{array}{r}5 \cdot 60 \\
\cdot 43 \\
\end{array}$ & $\begin{array}{r}5 \cdot 72 \\
\cdot 54 \\
\end{array}$ \\
\hline \multicolumn{4}{|c|}{ 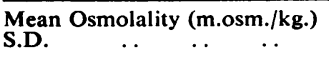 } & $\cdots$ & $\begin{array}{l}\cdots \\
\cdots\end{array}$ & $\begin{array}{l}800 \\
245\end{array}$ & $\begin{array}{l}687 \\
225\end{array}$ & $\begin{array}{l}760 \\
222\end{array}$ & $\begin{array}{l}662 \\
225\end{array}$ & $\begin{array}{l}572 \\
206\end{array}$ & $\begin{array}{l}688 \\
247\end{array}$ \\
\hline
\end{tabular}


The distribution of urinary $\mathrm{pH}$ values is given in Table II. In each area the mean $\mathrm{pH}$ of the urines from females is higher than that of those obtained from males.

TABLE II

DISTRIBUTIONS OF $p H$ OF EARLY MORNING URINE SPECIMENS

200 Males and 178 Females, aged 15 to 65 years, in three areas in South Wales

\begin{tabular}{|c|c|c|c|c|c|c|c|}
\hline \multirow{2}{*}{ Sex } & \multirow{2}{*}{ Area } & \multicolumn{6}{|c|}{ pH Range } \\
\hline & & $4 \cdot 5$ & $5 \cdot 0$ & $5 \cdot 5-$ & $6 \cdot 0$ & $6 \cdot 5-$ & $7 \cdot 0$ \\
\hline \multirow{4}{*}{ Male } & Mining Valley & 2 & 28 & 20 & 10 & 2 & 2 \\
\hline & Rural Village & 0 & 36 & 20 & 6 & 2 & 1 \\
\hline & Suburban & 4 & 29 & 26 & 11 & 1 & 0 \\
\hline & Total & 6 & 93 & 66 & 27 & 5 & 3 \\
\hline \multirow{4}{*}{ Female } & Mining Valley & 2 & 21 & 17 & 16 & 5 & 1 \\
\hline & Rural Village & 1 & 22 & 22 & 9 & 0 & 1 \\
\hline & Suburban & 3 & 18 & 23 & 11 & 5 & 1 \\
\hline & Total & 6 & 61 & 62 & 36 & 10 & 3 \\
\hline
\end{tabular}

These differences are not significant (at the level $\mathrm{P}<0.05)$ and in the rural village the difference in means is very small. Bartlett's test of homogeneity (Bartlett, 1937) shows that there are no significant differences between the variances of the distributions of $\mathrm{pH}$ in the three areas (Males $\mathrm{F}=1.08 ; 0.7>\mathrm{P}>$ $0 \cdot 5$. Females $F=3 \cdot 04 ; 0 \cdot 3>P>0 \cdot 2$ ). Analysis of variance shows that there is no significant difference between the means of the three areas. The results were, therefore, combined. The distributions of $\mathrm{pH}$ show positive skewness in both sexes. The mean for the three populations combined is $5 \cdot 59$ (S.D. $0 \cdot 45$ ) in males and 5.71 (S.D. 0.51 ) in females. The difference between these means is significant $(t=$ $2.35 ; 0.02>\mathrm{P}>0.01)$. The frequency of urine $\mathrm{pH}$ below 6.0 was significantly greater amongst the urines from males, than amongst those from females (Table III). The regression coefficients for $\mathrm{pH}$ on age are 0.003 in females and -0.001 in males; neither of these is significant. There is, therefore, no significant effect of age on urinary $\mathrm{pH}$ in the age range studied.

\section{TABLE III}

DIFFERENCES IN PH IN EARLY MORNING URINE SPECIMENS

Males and Females, aged 15 to 65 years, in three areats in South Wales

\begin{tabular}{ll|c|c|c}
\hline pH &. & $4.5-$ & $6.0-$ & Total \\
\hline Males $\ldots$ & $\ldots$ & 165 & 35 & 200 \\
Females.. & $\cdots$ & 129 & 49 & 178 \\
\hline & $\chi^{2}-4.91 ; 0.05>P>0.02$.
\end{tabular}

The distribution of urinary osmolality is given in Table IV. In all three areas the mean osmolality of the urines obtained from males is greater than that of those obtained from females. This difference is significant in the Rhondda Fach and in the Vale of Glamorgan (for each $\mathrm{P}<0.01$ ), whereas it is not significant in the suburban area of Cardiff $(0 \cdot 1>$ $P>0 \cdot 05$ ). No significant differences between the variances of the urinary osmolalities in the three areas were found (Males $F=0.79 ; 0.7>P>0.5$ Females $\mathrm{F}=1 \cdot 83 ; 0 \cdot 5>\mathrm{P}>0 \cdot 3)$. Further analysise however, shows that for both males and females there are significant differences $(P<0.05)$ in the means for the three areas. There is thus a suggestion of geographical differences in osmolality, with the population of the rural village having lower values than that of the other areas. Despite this difference in populations, we have for convenience combined the osmolality results. The overall mean osmolality for the three populations is $749 \mathrm{~m} .0 \mathrm{sm} . / \mathrm{kg}$. (S.D.

TABLE IV

DISTRIBUTIONS OF OSMOLALITY OF EARLY MORNING URINE SPECIMENS 200 Males and 178 Females, aged 15 to 65 years, in three areas in South Wales

\begin{tabular}{|c|c|c|c|c|c|c|c|c|c|c|c|c|c|c|c|c|}
\hline \multirow{2}{*}{ Sex } & \multirow{2}{*}{ Area } & \multicolumn{15}{|c|}{ Osmolality Range (m.osm./kg.) } \\
\hline & & $100-$ & 200 & 300 & 400 & 500 & 600 & 700 & 800 & $900-$ & 1000 & 1100 & 1200 & $1300-$ & 1400 & 1500 \\
\hline \multirow{4}{*}{ Male } & Mining Valley .. & 0 & 0 & 3 & 7 & 6 & 2 & 12 & 17 & 8 & 3 & 3 & 0 & 1 & 1 & 1 \\
\hline & Rural Village & 1 & 4 & 2 & 7 & 11 & 5 & 11 & 10 & 11 & 3 & 0 & 0 & 0 & 0 & 0 \\
\hline & Suburban & 1 & 0 & 1 & 7 & 8 & 12 & 12 & 13 & 11 & 1 & 2 & 2 & 1 & 0 & 0 \\
\hline & Total & 2 & 4 & 6 & 21 & 25 & 19 & 35 & 40 & 30 & 7 & 5 & 2 & 2 & 1 & 1 \\
\hline \multirow{4}{*}{ Female } & Mining Valley & 0 & 1 & 8 & 7 & 14 & 5 & 10 & 6 & 8 & 1 & 1 & 1 & 0 & 0 & 0 \\
\hline & Rural Village ... & 0 & 3 & 10 & 11 & 10 & 9 & 3 & 4 & 3 & 2 & 0 & 0 & 0 & 0 & 0 \\
\hline & Suburban & 0 & 2 & 4 & 8 & 12 & 9 & 6 & 7 & 5 & 5 & 1 & 1 & 1 & 0 & 0 \\
\hline & Total $\quad$. & 0 & 6 & 22 & 26 & 36 & 23 & 19 & 17 & 16 & 8 & 2 & 2 & 1 & 0 & 0 \\
\hline
\end{tabular}


234) in males and 643 m.osm./kg. (S.D. 231) in females. The difference between these means is highly significant $(t=4.42 ; \quad \mathrm{P}<0.001)$. The frequency distribution of osmolalities of male urine shows negative skewness whereas that of female urine shows positive skewness.

In both sexes the osmolality of early morning urine specimens decreases significantly with age. The association between osmolality and age is given by the following regression equations:

$$
\begin{array}{ll}
y \text { (males) } & =-4.41 \chi \text { (males) }+914 \\
y \text { (females) } & =-4.94 \chi \text { (females) }+834
\end{array}
$$

where $y=$ osmolality in $\mathrm{m} . \mathrm{osm} . / \mathrm{kg}$.

and $\chi=$ age in years.

Both regression coefficients are highly significant $(P<0 \cdot 001)$. Covariance analysis of osmolality and age shows no significant difference in the slopes of the regression coefficients of males and females $(F<1)$ but there is a significant difference $(F=18.96)$ in their positions. The difference between the osmolality of early morning specimens of urine of males and females is, therefore, real and is not dependent on age differences between the males and females included in this study.

The urines from six subjects (one male and five females) were infected, but the urinary $\mathrm{pH}$ and osmolality differences between the sexes remain significant when the results obtained on these infected urines are excluded from analysis.

The relationship between $\mathrm{pH}$ and osmolality was examined by covariance analysis. The regression coefficients of $\mathrm{pH}$ on osmolality are -0.0007 in males and -0.0006 in females. There is no significant difference in the slopes or positions of the regression lines. A common regression line was derived from the overall data for $\mathrm{pH}$ and osmolality with a regression coefficient of -0.0006 . This analysis shows that for any given osmolality there is no significant difference in mean urinary $\mathrm{pH}$ of males and females. Osmolality and $\mathrm{pH}$ are, therefore, interdependent variables.

\section{Discussion}

Sex differences in urinary $\mathrm{pH}$ and osmolality have not been previously recorded. Henderson and Palmer (1913) studied urinary pH in 100 normal subjects but failed to state the sex of their urine donors. Maslow (1936) confined his study to 141 male students. The means for urinary $\mathrm{pH}$ quoted by these authors, 6.03 and 6.02 respectively, are higher than those observed in the present study (5.59 in males and 5.71 in females). This discrepancy is probably largely due to the fact that our means refer to early morning urine specimens, whereas those of Henderson and Palmer (1913) and Maslow (1936) refer to random and 24-hour urine collections respectively.

The present observations establish that the mean $\mathrm{pH}$ of early morning urine specimens from females is significantly higher than that of similar specimens obtained from males, and that the mean osmolality of early morning urine specimens is significantly higher in males than in females. The explanation(s) for these differences are not known. The possibility that the sex difference in urinary $\mathrm{pH}$ is due to the inclusion of pregnant women must be considered, for Asscher and others (1966) showed that, even in the early stages of pregnancy, urinary $\mathrm{pH}$ is greatly raised as compared with non-pregnant controls. This explanation is unlikely since the mean urinary $\mathrm{pH}$ of the sixty females above child-bearing age (over 45$)$ included in this study, was higher $(5 \cdot 73)$ than the mean for all females $(5 \cdot 71)$. It seems more likely that the sex difference in urinary $\mathrm{pH}$ is due to the higher protein intake of men as compared with women (Widdowson and McCance, 1936), for it has long been known (Bernard, 1878; Hunt, 1956) that a high protein intake leads to the excretion of a more acid urine. The sex difference in urinary osmolality may also be related to differences in the protein intake of men and women. SchmidtNielsen, Pfeiffer, and Robinson (1966) showed that, in the rat, a high protein intake leads to an increase in the urea concentration of the renal papilla and thus to enhanced water reabsorption from the collecting ducts and the excretion of a more concentrated urine. The hypothesis that the sex difference in urinary $\mathrm{pH}$ and osmolality share a common cause (i.e. the sex difference in protein intake) is supported by the observation that urinary pH and osmolality are interdependent variables, although other factors, such as fluid intake, may be involved. Variations in the pattern of fluid intake may be a factor in the geographical difference in osmolality found in rural and urban populations.

In both sexes, urinary osmolality was found to decrease with age. This observation is in keeping with the finding of Lewis and Alving (1938) that urinary concentrating power in males declines with age.

The existence of a sex difference in urinary $\mathrm{pH}$ may have wider implications. For example, urinary $\mathrm{pH}$ is an important facter in the pathogenesis of urinary calculi (McGeown and Bull, 1957; MetcalfeGibson, McCallum, Morrison, and Wrong, 1963). It also affects the excretion of several drugs (Milne, Schribner, and Crawford, 1958; Milne, 1965) and some metabolic products (Bourke, Copeman, Milne, and Stokes, 1966), and influences the activity of 
antibacterial drugs on urinary pathogens (Mou, 1962; Brumfitt and Percival, 1962; Tallgren and von Bonsdorff, 1965). The magnitude of the effect of the sex difference in urinary $\mathrm{pH}$ in relation to these fields of study requires further evaluation.

\section{SUMmary}

In three communities in South Wales, the $\mathrm{pH}$ and osmolality of early morning urine specimens obtained from 200 males and 178 females, aged 15 to 65 years, were measured. The mean $\mathrm{pH}$ of the urine from males $(5 \cdot 59)$ is significantly lower than that of the urine from females $(5 \cdot 71)$. No significant effect of age on $\mathrm{pH}$ was found. The mean osmolality of the urine from males is higher than that of the urine from females, and geographical differences in the mean osmolalities were also found. In both sexes there is a decrease in osmolality with increasing age. Urinary $\mathrm{pH}$ and osmolality are interdependent variables.

We are grateful to Prof. A. L. Cochrane and Dr H. Campbell for their helpful advice, to the field survey team of the M.R.C. Epidemiological Research Unit (South Wales) for their co-operation, to Miss S. Chick for technical assistance, and to Miss M. Abernethy for the statistical analyses.

\section{REFERENCES}

Asscher, A. W., Sussman, M., Waters, W. E., Davis, R. H., and Chick, S. (1966). Lancet, 2, 1037.

Bartlett, M. S. (1937). J. roy. statist. Soc., 4, Suppl., p. 137.

Bernard, C. (1878). "An Introduction to the Study of Experimental Medicine", trans. H. C. Greene (1927). Macmillan, New York. Cited by Hunt (1956).

Bourke, E., Copeman, P. W. M., Milne, M. D., and Stokes, G. S. (1966). Lancet, 1, 1394.

Brumfitt, W., and Percival, A. (1962). Ibid., 1, 186.

Henderson, E. J., and Palmer, W. W. (1913). J. biol. Chem., 13, 393.

Hunt, J. N. (1956). Clin. Sci., 15, 119.

Lewis, W. . (19nd Alving A S (1938). Amer. J Physiol. 123,500 .

Maslow, L. A. (1936). J. Urol. (Baltimore), 35, 674.

McGeown, M. G., and Bull, G. M. (1957). Brit. med. Bull., 13, 53.

Metcalfe-Gibson, A., McCallum, F. M., Morrison, R. B. I., and Wrong, O. (1963). "Proc. II Int. Congr. Nephrol., Prague", p. 813.

Milne, M. D. (1965). Proc. roy. Soc. Med., 58, 961.

-, Schribner, B. H., and Crawford, M. A. (1958). Amer. J. Med., 24, 709.

Mou, T. W. (1962). J. Urol. (Baltimore), 87, 978.

Schmidt-Nielsen, B., Pfeiffer, E. N., and Robinson, R. R. ㅇ (1966). "Abstracts III Int. Congr. Nephrol.", vol. 2, p. 268.

Tallgren, L. G., and von Bonsdorff, C. H. (1965). Acta med. scand., 178, 543.

Widdowson, E. M., and McCance, R. A. (1936). J. Hygo (Lond.), 36, 293. 